\title{
Learner-centered teaching in a Higher Education course: a case study with a recognized researcher in Sports Coaching
}

Ensino centrado no aprendiz em um curso no Ensino Superior: estudo de caso com um pesquisador reconhecido no Coaching Esportivo

Enseñanza centrada en el aprendiz en un curso de Educación Superior: un estudio de caso con un investigador reconocido en Coaching Deportivo

Received: 03/05/2021 | Reviewed: 03/11/2021 | Accept: 03/15/2021 | Published: 03/21/2021

Heitor de Andrade Rodrigues

ORCID: https://orcid.org/0000-0002-9456-4821

Universidade Federal de Goiás, Brasil

Email: heitor@ufg.br

Vinicius Zeilmann Brasil

ORCID: https://orcid.org/0000-0003-0036-494X

Universidade Estadual de Santa Catarina, Brasil Email: vzbrasil@hotmail.com

Michel Milistetd

ORCID: https://orcid.org/0000-0003-3359-6878

Universidade Federal de Santa Catarina, Brasil Email: michel.milistetd@ufsc.br

Pierre Trudel

ORCID: https://orcid.org/0000-0003-4883-5229

University of Ottawa, Canada Email: ptrudel@uottawa.ca

\begin{abstract}
Sport coaching researchers have provided generous recommendations on the importance of developing coach education programs based on learner-centered teaching (LCT) principles. However, empirical studies are rare, and without concrete examples, administrators and instructors will be reluctant to adopt this approach. In this case study, we used Weimer's $(2002,2013)$ five dimensions of LCT to analyze (a) the perspective of a recognized researcher in the LCT coach development field, (b) his course plan and delivery strategy, and (c) the students' perceptions of this course. A qualitative approach was used and included different tools to collect the data. The first two authors attended all the lessons, participated in all the learning activities, and took notes in a reflective journal. At the end of the semester, they conducted a semi-structured interview to get the instructor's perspective on the LCT approach. Finally, an e-mail was sent to the students to collect their perceptions. The data were analyzed and interpreted using concept mapping, and Weimer's five dimensions. The results showed that (a) most of the LCT dimensions were respected in the planning and delivery of the course, (b) there were times when the instructor felt uncomfortable playing a less important role, and (c) most students had positive learning experiences, although some have been taken out of their comfort zone with this new teaching approach. The article ends with a reflection on the recent impact of COVID-19 on education in Higher Education (HE).
\end{abstract}

Keywords: Coach education; Learner-centered teaching; Online courses; Higher education.

\section{Resumo}

Os pesquisadores do coaching esportivo forneceram recomendações generosas sobre a importância de desenvolver programas de formação de treinadores com base nos princípios do ensino centrado no aprendiz (ECA). No entanto, os estudos empíricos são raros e, sem exemplos concretos, os gestores e professores relutarão em adotar essa abordagem. Neste estudo de caso, usamos as cinco dimensões do ECA de Weimer $(2002,2013)$ para analisar (a) a perspectiva de um pesquisador reconhecido no campo de desenvolvimento de treinadores sobre o ECA, (b) seu plano de curso e estratégia de ensino, e (c) as percepções dos alunos. A abordagem qualitativa foi usada e incluiu diferentes ferramentas para coletar os dados. Os dois primeiros autores assistiram a todas as aulas, participaram de todas as atividades de aprendizagem e tomaram notas em um diário reflexivo. No final do semestre, conduziram uma entrevista semiestruturada para obter a perspectiva do instrutor sobre a abordagem do ECA. Por fim, um e-mail foi enviado aos alunos para coletar suas percepções. Os dados foram analisados e interpretados por meio de mapeamento conceitual, a partir das cinco dimensões de Weimer. Os resultados mostraram que (a) a maioria das dimensões do ECA foi respeitada no planejamento e desenvolvimento do curso, (b) houve momentos em que o instrutor se sentiu 
desconfortável em desempenhar um papel menos importante, e (c) a maioria dos alunos teve experiências de aprendizagem positivas, embora alguns tenham saído de sua zona de conforto com a abordagem de ensino. O artigo termina com uma reflexão sobre o impacto recente da COVID-19 na educação no Ensino Superior.

Palavras-chave: Formação de treinadores; Ensino centrado no aprendiz; Cursos online; Ensino superior.

\section{Resumen}

Los investigadores del coaching deportivo han proporcionado recomendaciones generosas sobre la importancia de desarrollar programas de educación para entrenadores basados en los principios de la enseñanza centrada en el aprendiz (ECA). Sin embargo, los estudios empíricos son raros y, sin ejemplos concretos, los administradores e instructores se mostrarán reacios a adoptar este enfoque. En este estúdio de caso, utilizamos las cinco dimensiones del ECA de Weimer $(2002$, 2013) para analizar (a) la perspectiva de un investigador reconocido en el campo del desarrollo de coaches sobre el ECA, (b) su plan de curso y estrategia de enseñanza, y (c) las percepciones de los estudiantes. Se utilizó un enfoque cualitativo e incluyó diferentes herramientas para recopilar los datos. Los dos primeros autores asistieron a todas las lecciones, participaron en todas las actividades de aprendizaje y tomaron notas en un diario reflexivo. En Al final del semestre, llevaron a cabo una entrevista semiestructurada para obtener la perspectiva del instructor sobre el enfoque del ECA. Finalmente, se envió un correo electrónico a los estudiantes para recoger sus percepciones. Los datos se analizaron e interpretaron mediante el mapeo de conceptos, basado en las cinco dimensiones de Weimar. Los resultados mostraron que (a) la mayoría de las dimensiones del ECA fueron respetadas en la planificación y ejecución del curso, (b) hubo momentos en que el instructor se sintió incómodo al desempeñar un papel menos importante y (c) la mayoría de los estudiantes tuvieron experiencias de aprendizaje positivas, aunque algunos han sido sacados de su zona de confort con este enfoque de enseñanza. El artículo finaliza con una reflexión sobre el impacto reciente de la COVID-19 en la educación en Educación Superior.

Palabras clave: Formación de entrenadores; Enseñanza centrada en el aprendiz; Cursos online; Educación superior.

\section{Introduction}

When compared to other fields of research, the science of sport coaching is in its infancy with its 50 years of existence. Gilbert and Trudel (2004) in their review of the literature on sport coaching for the period of 1970-2001 found that: (a) a total of 610 articles were published, (b) in the early 1970s, there was an average of one article published per year compared to 30 articles from the 1990 s, (c) articles were published in 161 different journals of which $62 \%$ were concentrated in 20 journals, (d) the main research topic was the behaviors of athletes and coaches (50\%) while 33\% of articles focused on coaches' career development (e.g., coach education, satisfaction, burnout), and (e) quantitative methodology was predominant $(80 \%)$ and questionnaires were the most common instrument (70\%). Recently, Griffo et al (2019), replicated the study for the period of 2005-2015. The authors found that (a) 612 articles were published in 119 different journals, (b) the average number of articles published per year increased from 30 to 87, (c) the main research topic was sports psychology (43\%), followed by coaching methods (31\%) and coach education (17\%), and (d) quantitative methodology (49\%) was used slightly more than qualitative methodology (44\%). Galatti et al. (2016) used the same methodology to analyze the sport coaching literature (20002015) in eight journals published in Brazil. The analysis revealed that (a) a total of 82 articles were found, (b) the average number of articles per year increased from two to three up until 2008 to nine for the last seven years, (c) the main research topics were coaches' thinking (e.g., perception, belief) (37\%), coaches' behaviors (e.g., leadership style, behaviors) (33\%), and career development (e.g., education, certification) (24\%), and (d) qualitative methodology (49\%) was more popular than quantitative methodology (40\%). They concluded that "researchers in Brazil are aligning their efforts with the international research agenda on sports-coaching - although years later" (p. 322). As these three reviews of literature have shown, researchers' interest for coach education has grown over the years.

Due to the important role played by coaches, many countries now have their own coach education programs (Callary, Culver, Werthner, \& Bales, 2014) (see International Journal of Sport Coaching, section Coaching In) developed by their national governing body or their sport federations. Given the characteristics of the programs, they can be grouped into two categories. The small-scale programs are developed for a specific and limited group of coaches, and the large-scale programs are those where the main objective is to train and certify as many coaches as possible in different coaching contexts. The 
content and duration of these programs are far from similar (Callary et al., 2014; Milistetd et al., 2016). A number of studies on the relevance of these programs shows different results. For some coaches, these programs helped to learn the basics of their sport and to familiar themselves with the sport sub-culture (Vella, Crowe, \& Oades, 2013; Werthner, \& Trudel, 2009; Wiersma, \& Sherman, 2005). For other coaches, these programs (a) are too expensive and time consuming, (b) contain the content that does not respond to the reality of their coaching context, (c) place coaches in a passive role, and (d) focus mainly on techniques and tactics without developing the ability to reflect on coaching practice (Cushion \& Nelson, 2013; Menezes, Modolo, Dos Santos, \& Musa, 2017). Arguably, the main problem with these programs is that the focus is too much on the content and not enough on the learner. In an extensive review of the literature on coach education programs, Paquette and Trudel (2016) concluded that the majority of critiques and recommendations targeting coach education programs can be addressed by shifting from an instructor/content-centered approach to a learner-centered approach.

In an attempt to have sports coaching recognized as a profession (Duffy et al., 2011), researchers have suggested developing, or better organizing, the coach education programs offered by higher education (HE) institutions (Mallett, Rynne, \& Dickens, 2013; McCarthy \& Stoszkowski, 2018; Zakrajsek, Thompson, \& Dieffenbach, 2015). As such, the International Council for Coaching Excellence (ICCE) has produced a document entitled 'International Sport Coaching Bachelor Degree Standards' to be used as a point of reference for developing and managing a bachelor coaching degree (Lara-Bercial et al., 2016). Interestingly, studies on HE coach education programs are very recent. Trudel, Milistetd and Culver (2020) found 38 articles published between 2000-2018, including 28 in the last five years. Analysis of these empirical studies indicated that (a) 24 studies come from UK and 3 from Brazil, (b) only 12 studies look at the impact of the whole program, the others focus on one course (12 weeks) or on the internship, and (c) in 24 studies, the researchers tested a strategy to help the student-coaches become familiar with reflective practice. In short, compared to small and large-scale coach education programs developed by national governing bodies or sports federations, an attempt is made to place the learner at the center of the learning process in the coach education programs developed by HE. Mallett, Rynne and Dickens (2013), in a position paper on the development of high-performance coaches in Australia, concluded: "University courses in high performance sports coaching should consider the incorporation of authentic tasks, provision of opportunities for collaboration, offer a learner-centered approach and provide authentic and integrated assessment tasks to be applied to coaching contexts" (p. 468).

Studies on HE coach education programs are of particular importance for Brazilian coaches, since coaching is a profession and practicing coaches must have a bachelor's degree in physical education (Baptista, Leite, Falcão, \& Flausino, 2015). Recently, Milistetd, Trudel, Mesquita and do Nascimento (2014) analyzed the curriculum of different bachelor programs across the country. In a first study about the bachelor's degree offered by 20 universities, the authors found that (a) many of the student-coaches entered the program with limited athletic and coaching experiences, (b) the program prepared them to work in different contexts (leisure, health, and sports performance), and (c) their preparation was insufficient to take a position in the 'performance coaching' area.

In the second study (Milistetd, Trudel, Rynne, Mesquita, \& do Nascimento, 2018; Milistetd, Ciampolini, Mendes, Cortela, \& do Nascimento, 2018), the researchers analyzed the learner-centeredness of the bachelor offered by one university, using the five dimensions of learner-centered teaching (LCT) framework as proposed by Weimer (Weimer, 2002; Weimer, 2013). The results indicated that the university's official documents contained many references to a learner-centered approach (e.g., students should play an active role, develop critical attitude and autonomy, etc.) but, at the same time, there were directives that reinforced the traditional approach (e.g., 75\% of attendance is required, limited possibility to choose courses, etc.). A strong preference for an instructor/content-centered approach was confirmed in the analysis of the course syllabi and the transcription of interviews with the professors and the students. Based on the findings of these studies, the researchers decided to plan and deliver a mandatory Sport Pedagogy course based on the LCT principles (Milistetd, Salles, Backes, 
Mesquita, \& Nascimento, 2019). The main results were (a) the institutional requirements sometimes limited the implementation of learning activities, (b) the five dimensions should be introduced gradually, (c) the level of student participation varied, (d) the students constantly compared this course with other courses designed with the traditional approach and, as good 'strategic learners' (De Martin-Silva, Fonseca, Jones, Morgan, \& Mesquita, 2015), they put their efforts on courses where the instructors loaded the students with material to achieve high grades, and (e) from the instructors' perspective, LCT required investing a lot of time planning the course and keeping track of the learning as the semester progressed.

We must recognize that, up to now, researchers in sports coaching have been generous with their prescriptions for LCT but empirical studies of LCT are rare (Armour, 2010; Trudel, Culver, \& Werthner, 2013). Without concrete examples of how it can be done, administrators and instructors will be reluctant to make this crucial change (Milistetd, Salles, Trudel, \& Paquette, 2019; Paquette \& Trudel, 2018; Stodter \& Cushion, 2016). Therefore, the goal of this case study was to use Weimer's (Weimer, 2002; Weimer, 2013) five dimensions of LCT to analyze (a) the perspective of a recognized researcher in the LCT coach development field, (b) his course plan and delivery strategy, and (c) the students' perceptions of this course.

\section{Method}

\section{Research context}

About the method, we choose a case study approach, which is recommended in the investigation of complex social phenomena and because it allows to understand real-life events. More than the choice of a method, the case study is the choice for the investigation of a unique and particular phenomenon (Sparkes \& Smith, 2014). The particular phenomenon is represented by professor Dr. Pierre Trudel course with a group of 16 graduate students. Pierre has been teaching at the University of Ottawa (Canada) for 30 years and his main research interest is the learning and development of sport coaches. He has received awards for the quality of his teaching, has published many articles on the role of the learner in the teachinglearning process (Paquette \& Trudel, 2016; Trudel, Culver, \& Werthner, 2013; Trudel, Gilbert, \& Werthener, 2010; Trudel, Gilbert, \& Rodrigue, 2016), and is known internationally (e.g., Chair of the ICCE's research group for seven years, editor or assistant editor of numerous journals). For many years, Pierre has been teaching a course entitled 'APA 5311 Analysis and Enhancement of Interventions in Sport, Physical Activity and Health Settings' to a group of students ( $\mathrm{n}=12$ to 16) enrolled in a master's degree program that prepares students to work with athletes and coaches as sport psychologists/mental training consultants. During this course, consisting of 13 lessons of three hours each, students were exposed to learning activities intended to introduce them to working with coaches to better reflect on their coaching practice.

\section{Data collection and analysis}

The first two authors of the article had the opportunity to attend Pierre's course as visiting professors. The LCT framework of Weimer (2002; 2013) was chosen to plan, conduct, and analyze the data collected. For Weimer (2013) the learning-centered label is often used to design any strategy that engages students and argues that "learner-centered teaching has characteristics that make it unique and that differentiate it from active learning and other forms of student engagement” (p. IX). For Weimer (2013) in order to develop and evaluate courses based on the LCT principles, five key dimensions must be considered, the: role of the teacher; balance of power; function of content; responsibility for learning; and purposes and processes of evaluation. A brief description of these five dimensions is included in the Table 3, a reprint from the article by Milistetd, Trudel, Rynne, Mesquita, \& do Nascimento (2018). Weimer's framework has inspired many other researchers (Blumberg, 2009; Cullen, Harris, \& Hill, 2012; Harris \& Cullen, 2010), and has been used to analyze sport coach education programs (Paquette \& Trudel, 2016; Milistetd, Trudel, Rynne, Mesquita, \& do Nascimento, 2018). 
In this study, the researchers used different techniques to collect the data. The first two authors attended all lessons; participated in all the learning activities; took notes in a reflective journal about what happened before, during, and after the lessons; and had frequent discussions. At the end of the semester, they conducted a semi-structured interview (45 minutes) to get Pierre's perspective on the LCT approach and how the course went during the semester. The students $(n=16)$ also had the opportunity to give their perceptions of the course. An email was sent to them stating that they were (a) free to participate, (b) their participation would not influence their final grade, (c) Pierre would not know who had participated, and (d) no name would appear on any document. To make it easier for the students, Table 3 was provided in which the right column was empty and titled 'Student perceptions'. Eleven students emailed their completed table to the first author.

For the purpose of this article, the researchers carefully read the different data sources. Then, it was decided to present the results using two strategies. First, a concept map (see Figure 1) was used to map Pierre's perspective on the LCT (upper part) and to outline Pierre's planning and delivery of the course (lower part). Concept mapping, as developed by Novak (2010)., is based on educational theories with particular emphasis on meaningful learning. Using the free IHMC CmapTools software (http://cmap.ihmc.us), it was possible to organize the information, the themes, and their relationships in a visual fashion. For Moon, Hoffman, Novak, and Canas (2011) "Concept Maps are a powerful tool for capturing and representing expert knowledge, the first requirement for creating an effective system" (p. 10). In a recent article, Rodrigue, He, and Trudel (2016) discussed how concept mapping can be used to support sport coach development. To complement Figure 1, examples of events that demonstrate the use of LCT are provided for each dimension (see Table 3). The second strategy was to deductively analyze the comments that the 11 students had written in the table provided. All the comments relating to each dimension, usually consisting of a few sentences, were grouped and compared. Table 4 contains quotes that represent the main comments of students as well as quotes presenting a different opinion (* added).

\section{Trustworthiness}

We believe that the following points have helped to increase the credibility of the results and interpretations. First, the authors are university professors, with teaching and research experience, which qualifies them to understand the context and the language used by Pierre and the students. Second, several methods were used to collect data. Third, a peer (third author), with proven experience in qualitative sports coaching research, commented on a first version of the analysis. Fourth, a version of the article was sent to Pierre so that he could verify the accuracy of the facts and add comments he deemed relevant. All the suggested modifications were discussed in the finalization of the article.

The research purposes were approved by the Research Ethics Committee, according to CAAE number 03932718.3.0000.5083. In addition, the study was conducted with the consent of the participants.

\section{Results}

The results are presented in three parts: Pierre's perspective on LCT, Pierre's planning and delivery of the course, and the students' perceptions of the course. 


\section{Pierre's Perspective on LCT}

Figure 1. Pierre's perspective on the LCT (upper part ${ }^{1}$ ) and Pierre's planning and delivery of the course (lower part).

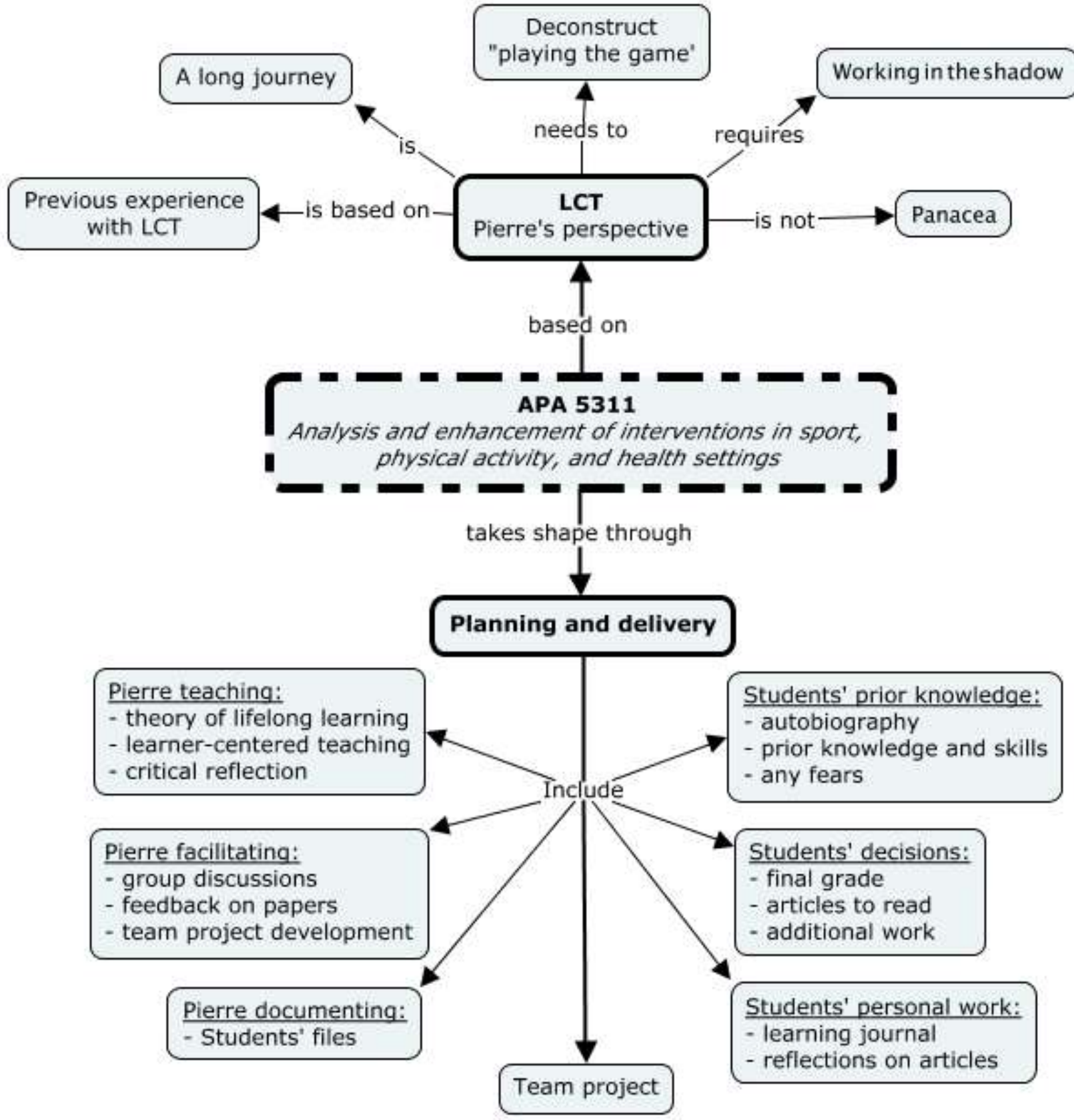

Source: Authors.

Pierre's interest in a teaching-learning process that gives a central role to the learner dates back to his graduate studies. His doctoral thesis was on an intervention to help sports coaches to self-assess in order to provide better learning opportunities for their athletes during training sessions. When he began his career as professor at the University of Ottawa (1987), he recalled a course in which students had to sign a 'personal learning contract' consisting of some mandatory tasks and assessments (60\%) and other optional, selected by the student according to his/her interest (40\%). Pierre underlined that at

${ }^{1}$ The upper part of Figure 1 is a visual representation of key elements of Pierre's perspectives regarding LCT. 
the university level, the implementation of the LCT principles is a long adventure never ended: "It took me years to develop the APA 5311 course as it is today, and every year I modify it". At the same time, not all the courses he teaches are based on the LCT principles: "In one course, I have at least 70 students, and in order for them to get their certification, I have to use material imposed by a national sport organization. So, I cannot give students a lot of choice regarding their reading and their evaluation".

At various points in the interview, Pierre uses the expression 'playing the game':

In the traditional approach, the profs and the students often play a game. The central rule is that the profs have to maintain a class average grade of less than $75 \%$ and, in introduction courses, failures are expected. In such a context, where it does not matter that a prof teaches well and that the students work hard, the latter have no choice and become strategic learners. Their thoughts and reactions are as follows: 'how can I get the best grade by working the less' or 'check often if this teaching material is important for the exam'. It's a question of cost benefit.

For Pierre, to establish an LCT context, it would be necessary to deconstruct this game, but it is a difficult task since most university administrators not only accept it but want to maintain it:

One of my doctoral students taught a course based on the LCT at another university and the department head asked him to review his grading approach, and if he refused, he was to lose his contractual position. Personally, I was met by my dean and my director to explain the distribution of my grades in a particular course. As full professor with tenure, I could allow myself a challenging discussion about the different teaching-learning perspectives. Interestingly, in both cases the students mentioned, when evaluating their course, that they worked harder and were more motivated than in other courses, and that the evaluation methods were fair. So, what was the problem? I believe that it is the fear that the department or faculty might be seen as easily giving grades, although only a few students had the highest grade. It seems that protecting the institution's image is more important than setting up fair and equitable learning conditions for students.

In a LCT approach, the main roles of the professors are to prepare the learning environment, let the students participate, and supervise but from a distance: "Because I spend a lot of time preparing for the lesson and observing quietly what is going on, some students might think that I am not working. Being in the shadow is often uncomfortable". To the last question 'Is there anything else to add?' Pierre said: "LCT should not be seen as a panacea. We must remember that it is always the learner who decides to learn or not to learn. Some students are uncomfortable with having more power and prefer 'playing the game'."

\section{Pierre's planning and delivery the course}

It is clear that the team project is the culminating activity around which all the other learning activities are linked (see lower part of Figure 1). In groups of three or four, the students must find a coach, learn about his/her biography, discuss the aspect of his/her coaching practice that he/she wishes to improve, develop with the coach a strategy that will be implemented for five weeks. For Pierre, the project gives students the opportunity to learn not only how to help a coach improve, but also how to work as a team and develop learning skills for their future:

They have done team projects in other courses, but I try to enrich those experiences with readings and discussions on what makes teamwork effective. I also meet each team during the project to help them and to see how they are working together. Finally, each week, they must agree among themselves on the score each member should receive as to the quality of their involvement in the project. I hope they will use what they learned in this course for a long time. 
We can explain Pierre's planning and delivery of the APA 5311 by looking at what he did (left side) and what the students are asked to do (right side).

Pierre's teaching, facilitating, and documenting. It was in the first two lessons that Pierre did most of his teaching. He presented Jarvis' theory of lifelong learning, the LCT approach, and the reflective practice approaches as well as a tool for students to assess the level (1-4) of their own reflections on the readings and on other tasks. A typical lesson afterwards consisted of Pierre doing a summary of the last lesson, then facilitating discussions in sub-group of two on the mandatory readings or on the presentation by some students of their optional readings. Pierre had a strategy to increase the probability that the students would read the articles: "I decided on the pairs for the discussions. So, for each lesson there was a new partner. If he/she has not read the articles, it becomes embarrassing. It is a form of peer pressure". To try to make the students responsible for their learning, they had to self-assess their reflections on the content (readings, discussions, etc.) of each lesson and also their reflections on their optional readings. These reflections were not assessed: "If I mark their reflections, the students will write what they think I want. However, I read them and if a student is out of track, I will meet with him/her. I am there to facilitate their learning". For Pierre, in an LCT course, the professor must be able to follow the learning path of each student: "I had a file for each student in which I put everything that the student does. It takes time but is so rich in information, and useful at the end of the semester to agree on the final grade".

What the students do. Between the first and second lesson, the students must write the table of content of their autobiography. The title of each chapter should evoke a significant moment that has contributed to where they are today. They should also list the knowledge and skills they have that will be useful in the team project, along with any fears. These activities had several objectives: "The students realize that learning is a long process and their diploma is only one part. The information allows me to better connect with each of them: Do they have coaching experience? What can I do to reduce their fears?". After the first lesson, the students had an important decision to make: "What is the final grade I am aiming for?" The criteria for their self-assessment (see Table 1 and Table 2) described what the students had to do to achieve a desired grade. This way of doing is new for most students but it changes the learning climate: "Knowing in advance that they will end up with a decent grade if they do what is required, decreases the stress and they can focus on real learning. There is no game to play". The course can be seen as a mix of individual work (reflections) and collaborative work (team project, discussions in sub-groups) but each student has defined his/her own workload. At the end of the semester, each student must send a general reflection explaining if he/she deserves the grade he/she asked for: "I told them: Write your final grade on a piece of paper, find a mirror, look at yourself in the mirror, and ask yourself: 'Do I deserve this grade?' If you lie, you lie to yourself'.

Table 1. Criteria for your self-assessment and final grade.

\begin{tabular}{|c|c|c|c|c|c|}
\hline Learning activities & $\begin{array}{c}\text { B } \\
\text { Acceptable }\end{array}$ & $\begin{array}{c}\text { B+ } \\
\text { Good }\end{array}$ & $\begin{array}{c}\text { A- } \\
\text { Very good }\end{array}$ & $\begin{array}{c}\text { A } \\
\text { Very very good }\end{array}$ & $\begin{array}{c}\text { A+ } \\
\text { Outstanding }\end{array}$ \\
\hline $\begin{array}{l}\text { 1. Entries in your learning } \\
\text { journal } / 12\end{array}$ & $\begin{array}{c}\text { Sept } 6 \& \text { Nov } \\
29 \\
+6\end{array}$ & $\begin{array}{c}\text { Sept } 6 \& \text { Nov } \\
29 \\
+7\end{array}$ & $\begin{array}{c}\text { Sept } 6 \& \text { Nov } \\
29 \\
+8\end{array}$ & $\begin{array}{l}\text { Sept } 6 \& \\
\text { Nov } 29 \\
\quad+8\end{array}$ & $\begin{array}{c}\text { Sept } 6 \text { \& Nov } \\
29 \\
+9\end{array}$ \\
\hline 2. Optional readings $/ 8$ & 0 & 1 & 2 & 4 & 5 \\
\hline 3. Your selection & - & - & - & $\begin{array}{c}1 \text { major article or } \\
\text { book } \\
\text { (to be approved) }\end{array}$ & $\begin{array}{c}\text { Concept map on } \\
\text { the content of the } \\
\text { course }\end{array}$ \\
\hline $\begin{array}{l}\text { 4. Team project } \\
\text { participation } / 10\end{array}$ & 8 & 9 & 10 & 10 & 10 \\
\hline $\begin{array}{l}\text { 5. Your Team project } \\
\text { (PowerPoint report \& } \\
\text { presentation) }\end{array}$ & Acceptable & Good & Very good & Very very good & Outstanding \\
\hline
\end{tabular}


Table 2. Description of the learning activities.

\begin{tabular}{|l|l|}
\hline Learning journal & $\begin{array}{l}\text { The reflections should be about the document(s) to read for the class and the discussions/ } \\
\text { presentations in class. Each reflection must be at least 600 words and hopefully at the level of } \\
\text { dialogic (3) / critical (4). Using the option 'add a comment' you have to indicate in the margin the } \\
\text { level 1-4. }\end{array}$ \\
\hline Optional reading & $\begin{array}{l}\text { Each reflection must be at least } \mathbf{6 0 0} \text { words and hopefully at the level of dialogic (3) / critical (4). } \\
\text { Using the option 'add a comment' you have to indicate in the margin the level 1-4. You can do } \\
\text { and send only one optional article per week (see Calendar of learning activities). You have to do } \\
\text { your reflection and send it to Pierre, 2 days before the class (i.e. Tuesday 13h00). You will } \\
\text { present your reflection to the group of students or to a sub-group. }\end{array}$ \\
\hline Your selection & $\begin{array}{l}\text { - 1 major article or book: The reflection must be at least } 1 \text { 1000 words and hopefully at the level } \\
\text { of dialogic (3) / critical (4). Using the option 'add a comment' you have to indicate in the margin } \\
\text { the level 1-4. } \\
\text { - Concept map on the content of the course. Must provide (a) 2 pages of review of literature on } \\
\text { the different tools for mapping, (b) Using Cmap tool, draw a 'concept map' and provide } \\
\text { description/comments. One meeting with Pierre at mid-semester. } \\
\text { You have to send your work to Pierre before Tuesday (13h00) November 20th. You will present } \\
\text { your reflection or concept map to the group of students or to a sub-group. }\end{array}$ \\
\hline Team participation & $\begin{array}{l}\text { Each week, where it is mentioned 'group email', the group will send the 'Brief report on the team } \\
\text { project meeting' (see Template). On a scale 0-10 (10= excellent participation) each member is } \\
\text { evaluated (by the group) based on his/her preparation to the meeting/participation to the } \\
\text { discussion/engagement for the work to be done. }\end{array}$ \\
\hline See Template for the PowerPoint report of your Team project \\
\hline Your Team project
\end{tabular}

Source: Authors.

Comments on Pierre's planning and delivery of the course. In Table 3, we have listed, for each dimension, examples of events noted during our observations of the lessons and in our analysis of the course syllabus. It was easy to find examples, but we would like to add some details and comments. First, during the first two lessons, some students showed a little resistance if one relies on the questions asked particularly in relation to the self-assessment criteria. Second, although most the students seemed to be fully engaged in the activities, on a few occasions we noticed some students who had not read the mandatory articles, and for the team project, the work was not distributed equally. Third, we hardly saw any students asking for feedback on their reflections. Finally, the distribution of the final grades was as follows: three students had A+, five had A, eight had A-. It should also be mentioned that during the semester, four students changed their final grade: two increased and two decreased.

Table 3. Comparisons of ICT and LCT, and examples of the use of LCT.

\begin{tabular}{|c|c|c|c|}
\hline Dimensions & $\begin{array}{c}\text { Instructor-Centered } \\
\text { Teaching } \\
\text { ICT }\end{array}$ & $\begin{array}{c}\text { Learner-Centered Teaching } \\
\text { LCT }\end{array}$ & $\begin{array}{c}\text { Examples found in the } \\
\text { course syllabus and class } \\
\text { observations }\end{array}$ \\
\hline The role of the instructor & $\begin{array}{l}\text { - Act as an expert who must } \\
\text { lecture or demonstrate the } \\
\text { course material; } \\
\text { - Encourage individual works; } \\
\text { - Ask questions and often } \\
\text { provide the answers; } \\
\text { - Put students in a passive role } \\
\text { of taking notes; } \\
\text { - Cover all material included in } \\
\text { the syllabus; }\end{array}$ & $\begin{array}{l}\text { - Act as a facilitator by guidins } \\
\text { students in activities; } \\
\text { - Encourage collaborative } \\
\text { works; } \\
\text { - Encourage students to ask } \\
\text { questions and come up with } \\
\text { potential answers; } \\
\text { - Use activities such as } \\
\text { simulations, debates, problem- } \\
\text { solving, etc.; } \\
\text { - Show flexibility on the } \\
\text { amount of material to cover } \\
\text { based on students' needs and } \\
\text { progress; }\end{array}$ & $\begin{array}{l}\text { - With the exception of the } \\
\text { first } 2 \text { classes, students did } \\
\text { most of the talking; } \\
\text { - The team project is central; } \\
\text { - Ask questions or comments } \\
\text { after the sub-group } \\
\text { discussions; } \\
\text { - Many opportunities to share } \\
\text { the outcomes of their reading } \\
\text { in sub-groups; } \\
\text { - Students can change their } \\
\text { final grade during the } \\
\text { semester; }\end{array}$ \\
\hline
\end{tabular}




\begin{tabular}{|c|c|c|c|}
\hline The balance of power & $\begin{array}{l}\text { - The courses belong to the } \\
\text { instructors and all instructors' } \\
\text { requirements should be found } \\
\text { in the course syllabus } \\
\text { - Instructors decide what to } \\
\text { learn, the activities and } \\
\text { assignments, assessment } \\
\text { weighting, the calendar (pace } \\
\text { and order); }\end{array}$ & $\begin{array}{l}\text { - Instructors discuss the course } \\
\text { syllabus and are open students } \\
\text { suggestions; } \\
\text { - Instructors provide students } \\
\text { with opportunities (a) to select } \\
\text { some of the } \\
\text { readings/assignments, (b) to } \\
\text { know (from day one) how } \\
\text { many points they need to get } \\
\text { for each letter grade, (c) to } \\
\text { self-evaluate some of their } \\
\text { works, (d) to evaluate their } \\
\text { colleagues' works; }\end{array}$ & $\begin{array}{l}\text { - Done during the first class; } \\
\text { - (a) of the } 58 \text { articles listed in } \\
\text { the course syllabus, } 15 \text { were } \\
\text { mandatory; } \\
\text { - (b) well explained (see } \\
\text { appendix); } \\
\text { - (c) students had to self-assess } \\
\text { their learning journal entries } \\
\text { and optional reading } \\
\text { summaries using a specific } \\
\text { tool; } \\
\text { - (d) students evaluated the } \\
\text { participation of their } \\
\text { colleagues in the team project; }\end{array}$ \\
\hline The function of content & $\begin{array}{l}\text { - Take for granted that all } \\
\text { students have similar } \\
\text { background; } \\
\text { - Allow students to memorize } \\
\text { content; } \\
\text { - All the content prescribed } \\
\text { must be covered for } \\
\text { subsequent courses; } \\
\text { - Develop knowledge base; }\end{array}$ & $\begin{array}{l}\text { - Consider students' previous } \\
\text { knowledge; } \\
\text { - Encourage students to } \\
\text { transform and reflect on the } \\
\text { content; } \\
\text { - Learning the content is } \\
\text { prioritized over covering it; } \\
\text { - Develop knowledge base and } \\
\text { learning skills (disagree with } \\
\text { each other; critical reflection); }\end{array}$ & $\begin{array}{l}\text { - Students had to write an } \\
\text { 'autobiography'; } \\
\text { - Students had to keep a } \\
\text { 'reflective learning journal'; } \\
\text { - Modifications in the course } \\
\text { syllabus was made if } \\
\text { necessary; } \\
\text { - The reflective process was } \\
\text { present in each of the students' } \\
\text { work, and the effectiveness of } \\
\text { teamwork was discussed; }\end{array}$ \\
\hline $\begin{array}{l}\text { The responsibility for } \\
\text { learning }\end{array}$ & $\begin{array}{l}\text { - Because students are not well } \\
\text { prepared to take full } \\
\text { responsibility, instructors use } \\
\text { strategies (often based on } \\
\text { grades) to control the learning } \\
\text { environment: mandatory } \\
\text { attendance, penalties for } \\
\text { missed deadlines or being late, } \\
\text { bonus points for ..., etc. } \\
\text { - Extrinsic motivation } \\
\text { predominates; }\end{array}$ & $\begin{array}{l}\text { - Because students can learn to } \\
\text { be more responsible for their } \\
\text { learning, instructors will co- } \\
\text { create the learning } \\
\text { environment and let students } \\
\text { experiment the benefits of } \\
\text { good time management and } \\
\text { the consequences of being } \\
\text { passive; } \\
\text { - Intrinsic motivation } \\
\text { predominates; }\end{array}$ & $\begin{array}{l}\text { - In the first class, Pierre made } \\
\text { it clear that each student is } \\
\text { responsible for his/her } \\
\text { involvement in the course; } \\
\text { - Pierre did not mark the } \\
\text { learning journal entries or } \\
\text { optional readings summaries } \\
\text { but mentioned that he will } \\
\text { provide feedback on any } \\
\text { papers if a student asks for it }\end{array}$ \\
\hline $\begin{array}{l}\text { The purpose and processes } \\
\text { of evaluation }\end{array}$ & $\begin{array}{l}\text { - Mainly summative (what } \\
\text { grades to give) to identify the } \\
\text { good students (can use the } \\
\text { normal curve); }\end{array}$ & $\begin{array}{l}\text { - Both formative and } \\
\text { summative to gauge the } \\
\text { students progress - to } \\
\text { determine whether learning is } \\
\text { happening; }\end{array}$ & $\begin{array}{l}\text { - Students were rarely absent } \\
\text { from classes }\end{array}$ \\
\hline
\end{tabular}

Source: Authors.

\section{Students' perspectives on the course}

Table 4 groups quotes taken from the documents sent by eleven students. General comments on the course suggest that Pierre was able to create a learning environment valued by the students, even if it was a new experience for most of them. Regarding the role of the instructor, it seems that Pierre explained the LCT principles well at the start of the semester, and was able to apply them by being a good facilitator. The balance of power surprised some students who subsequently appreciated its advantages, such as, among other things, the ability to better plan their agenda, and feeling less stressed. For the students, the content presented and discussed, and the reflections on their prior knowledge helped them to complete the team project and 
grow as a person. The students' comments on taking responsibility for their learning suggest that they liked this because it increased their intrinsic motivation. However, for many students, assuming this role was a novel experience. The purpose and the process of evaluation were seen as transparent and fair as they flowed from the effort that students were willing to put into the learning activities as defined in the course syllabus. Finally, some students (marked in Table 4 with an asterisk) completed the course despite sometimes missing the more traditional approach.

Table 4. Quotes from the students' perceptions of the APA5311 course.

\section{General comments about the course}

S2 $\quad$ The most engaging course I have ever taken. The environment created by the instructor was phenomenal. I wish more courses would use this format.

S7 I really enjoyed applying the content of this course, working with classmates, and having an environment where we could share our experiences and knowledge to learn.

S8 I used to excel in my undergrad when taking courses with an instructor. However, I believe I have experienced a lot more growth and learned a lot more with LCT.

S9 The typical education model isn't great. It was refreshing to finally have a professor doing things differently, regardless of what the institution wanted.

*S5 $\quad$ This course was very learner-centered, and it was nice to have a different concept of learning. Even though there were times when I wished the course was more structured, it may have been because this course was an entirely new experience.

The role of the instructor

S3 $\quad$ Often professors explain their philosophy and teaching style on the first day of class, but it is very rare that they are able to consistently perform within the framework of their philosophy. Throughout the semester, I had the impression that Pierre had invested in the success of his students.

S6 I didn't feel like he was teaching us. For the most part, he has been a facilitator of our learning. Much of what we learned was from things we learned from each other or by reflecting on our readings.

S10 Pierre was really a facilitator of this course rather than an instructor. He mostly asked questions and asked the group to discuss or reflect, rather than giving lectures.

*S1 Even though the structure was very flexible, I found that the readings were all very coaching and sport oriented. There should have been more variety in the readings prescribed to us.

The balance of power

S3 $\quad$ I really enjoyed the balance of "power". At first, I thought it was a joke. Out of all the teachers I have met, I have never had the opportunity to select my grade at the start of the course.

S4 The whole course has been designed to give students the opportunity to choose and get their grade based on the quantity and quality of work.

S6 Everything that we did felt like we had control of how much and how little we wanted to engage in the content. This class was so relaxed and stress free because we knew that we would get out it based on what we put in it.

S7 $\quad$ I have had a heavier class load than usual this semester. Therefore, I found it helpful to choose a grade that would allow me to be happy with my grade, while not needing to worry about how much work I had to do.

S8 I believe that having this balance of power would have encouraged me to be more open about my concerns, and also help me understand why I got the grade I got so I knew how I can improve myself for the future

The function of content

\begin{tabular}{|l|ll}
\hline S1 & Our prior knowledge has been discussed often and we have always been encouraged to discuss our views with those of
\end{tabular} our colleagues. Additionally, our learning journals were a great way to reflect not only on this week's readings, but also our discussions with our classmates.

S6 When I had to present work to my peers, I felt like I paid more attention to knowing the details of the articles so that I could best convey my knowledge to them. I didn't want to disappoint my peers, so I was driven to have better 


\begin{tabular}{|c|c|}
\hline & reflec \\
\hline S8 & $\begin{array}{l}\text { With our group project, we were able to implement and test some of the tools discussed, which was a much more } \\
\text { hands-on approach to learning. This approach has been very effective for me and has helped improve my effectiveness } \\
\text { as a mental performance consultant and as a student. }\end{array}$ \\
\hline S10 & $\begin{array}{l}\text { There was no memorization of the content like I have in other courses, but rather a reflection of previous knowledge / } \\
\text { experiences and how this applies to current concepts. }\end{array}$ \\
\hline S11 & $\begin{array}{l}\text { The fact that Pierre is able to consider the cognitive structure of each student in his class is great! We were never } \\
\text { supposed to sit down and learn the same things the same way. }\end{array}$ \\
\hline \multicolumn{2}{|c|}{ The responsibility for learning } \\
\hline S1 & $\begin{array}{l}\text { Our teacher has taken the approach that we are responsible for our learning and that is how it will be after school is } \\
\text { over - no one is going to keep watching us to make sure we continue to learn and grow. }\end{array}$ \\
\hline $\mathrm{S} 2$ & $\begin{array}{l}\text { I don't think it necessarily increased my intrinsic motivation, but it did increase my self-awareness of its lack. I found I } \\
\text { need structure and external accountability for myself to remain productive, but this class lacked this. It was good to } \\
\text { experience such an environment and I think it would have been useful for me to experience more educational } \\
\text { environments like this one as a young student. }\end{array}$ \\
\hline S3 & $\begin{array}{l}\text { There were times when I lacked the motivation to complete my job. During these times, I would often think of the } \\
\text { instructor on the first day saying: 'you decide what grade you get'. I was reminded why I am in school. The pressure to } \\
\text { complete the job can be for a variety of reasons, but Pierre laid the groundwork that made me feel like I was in charge } \\
\text { of my learning. It was a choice. }\end{array}$ \\
\hline S5 & $\begin{array}{l}\text { The responsibility was definitely placed on the students, whether or not we learned something from the material. We } \\
\text { could have chosen to do basic reflections and not put a lot of thought into the process and simply focus on earning } \\
\text { points. }\end{array}$ \\
\hline S11 & $\begin{array}{l}\text { I think we often fell that it is 'our job' to make sure that all of our students 'learn' everything on the curriculum. It } \\
\text { sounds so ridiculous. I guess it comes down to that expression: 'you can lead a horse to water, but you can't make it } \\
\text { drink'. }\end{array}$ \\
\hline *S9 & $\begin{array}{l}\text { Sometimes more instruction would be good, but also by not getting it, I was able to grow more. Sometimes it is } \\
\text { important to not get the easy answer and to be able to take control and be held accountable. }\end{array}$ \\
\hline \multicolumn{2}{|c|}{ The purpose and process of evaluation } \\
\hline S2 & $\begin{array}{l}\text { This is a much fairer assessment of the students. In the ICT, the students can be penalized for simply not having passed } \\
\text { the tests. }\end{array}$ \\
\hline S4 & $\begin{array}{l}\text { The grade I wanted depended on what I wanted to learn and my ability to show how it affected my cognitive structure, } \\
\text { mainly through deep reflective practice, and how I will apply the new knowledge beyond the MHK program. }\end{array}$ \\
\hline S6 & $\begin{array}{l}\text { The evaluation process was very transparent and easy to understand. I was happy with the grade I received because I } \\
\text { know I had chosen it for myself and I did the work that was required for this grade. }\end{array}$ \\
\hline S8 & $\begin{array}{l}\text { Receiving feedback from the professor and evaluating my work from my own perspective has been a very useful } \\
\text { approach in evaluating my work. The reflections and presentations were much more applied which was a great way to } \\
\text { demonstrate the learning. }\end{array}$ \\
\hline *S3 & $\begin{array}{l}\text { It would probably be the only thing I don't like about this course. After I finish the work necessary to get the grade I } \\
\text { wanted, I started to wonder if the quality of my work is up to par. Regardless of whether this is my 'best job or not', I } \\
\text { would prefer to have comments on my reflections. This would be in the learner's best interest as he can now compare } \\
\text { his personal assessments with those of the professor. }\end{array}$ \\
\hline
\end{tabular}

Source: Authors.

\section{Discussion}

Pierre's journey within the LCT seems similar to what other HE professors have experienced ${ }^{23}$. Although the learnercentered concept has been discussed for many decades, through for example the work of John Dewey and Carl Rogers, the LCT for HE is around 25 years old if we use the work of Barr and Tagg (1995) and Weimer (2002) as a starting point. Since 
HE institutions are generally slow to make structural changes to become LCT institutes (Harris \& Cullen, 2010) it makes sense that professors interested in LCT must expect a long journey. While it might be frustrating to move slowly, Blumberg (2009) cautioned against making drastic changes and proposed a gradual approach to change implementation. Students need to become familiar with an LCT approach, and the instructors must experience what it is to teach 'in the shadows'.

For Pierre, to move toward LCT, it is essential to stop 'playing the game' in which students adopt learning approaches to follow or bend the rules dictated by the instructors and encouraged by the HE institutions. This issue can be discussed using the literature on student approaches to learning (SAL) and its three main approaches: deep, surface, strategic (Blumberg, 2009; Gerritsen-van Leeuwenkamp, Joosten-ten Brinke, \& Kester, 2019). Students with a deep approach will participate in learning activities with the aim of extracting meaning and linking it to their previous knowledge. These students possess an intrinsic interest in learning. This contrasts with the surface approach in which the students tend to limit their participation to the reproduction of knowledge using memorization. In this approach, students are motivated to avoid failure. Finally, students who use a strategic approach to learning can use both of the previous two approaches, because in order to be successful they "tend to pay careful attention to course assessment criteria, actively search for clues about what is testable material, and develop high regulated methods of studying through purposeful organization of effort and the effective management of time, materials, and environments" (Faranda, Clarke, \& Clarke III, 2020, p. 4). Asikainen and Gijbels (2017, p. 205), in a systematic review, concluded that there is no "clear empirical evidence for the assumption that students develop towards more deep approaches during higher education".

Many authors have mentioned that LCT should not be seen as a panacea and therefore, we should avoid opposing the traditional approach with the LCT since being completely LCT is not realistic for all courses (Blumberg, 2009; Schweisfurth, 2015). Bridging the gap between ICT and LCT is not easy, but LCT should not be imposed and some courses might be better served with a traditional approach; and, as Pitino (2000) has written, "when you build bridges, you can keep crossing them" (p. 29). Another reason for not seeing LCT as a panacea is that any good examples of LCT, the present case study included, should not be seen as 'best practices' to be replicated because of "cultural differences in how assessment is regarded and what is valued in learning", which implies that "pedagogy cannot be divorced from the social and resource contexts in which it exists" (Schweisfurth, 2015, p. 260-261).

Pierre's discourse on how he designed and delivered the course APA 5311 conforms to the five dimensions of Weimer's LCT framework and promotes a constructivist approach: "Learners [graduate students] construct meaning by combining what they currently know [their biography] with the new information they are acquiring [the first 7 classes]. This makes learning a personal process and rules out any idea of learning as the mere transmission of knowledge" (Weimer, 2013, p. 40). Given the important place for collaborative work in LCT, projects carried out in groups should be favored. We will argue that the way the team project has been presented to and developed by the students makes it a kind of problem-based learning (PBL). PBL contributes to deep learning (Asikainen \& Gijbels, 2017; Dolmans, Loyens, Marcq, \& Gijbels, 2016) and has been suggested as an appropriate way to address many of the five dimensions of LCT (Blumberg, 2009).. Schmidt, Rotgans, and Yew (2019) mentioned that, although PBL has been defined differently over the years, there are six important characteristics, and these were present in the team project. First, a problem is used as the starting point. In the team project, the problem, represented by the aspect on which the coach wanted to work, was defined with the students, making the problem real. Having a problem that reflects the coaching reality is of great importance in PBL (Araya, Bennie, \& O'Connor, 2015; Jones \& Turner, 2006; Morgan, Jones, Gilbourne, \& Llewellyn, 2013). The second and third characteristics are that the students collaborated in small groups and the instructor provided flexible guidance. For five weeks, there were no lessons, to give each group (3-4 students) the freedom in their schedules to complete the team project, although two meetings of 90 minutes were offered with Pierre for feedback and suggestions. Fourth, the number of lectures was limited. The first two 
lessons were used to explain the LCT approach and the main trends in coach learning and development. The specific information needed when working with the coach had to be found by the students. Fifth, learning was to be student-initiated. As demonstrated by the results, the whole course was learner-centered. Finally, students should have had enough time for selfstudy. Although the students had to collaborate in the team project, they had a self-selected individual workload and were asked to write their own reflections at the end of each week.

One element that Pierre did not mention during the interview and which was almost absent in his planning and delivery, is the place of technology in the teaching-learning process. In fact, all the classes were face-to-face and with the exception of a platform where the students could find teaching materials, the use of emails to communicate and send paperwork or quick information, and a free online tool (CmapTools) to learn and prepare concept maps, no innovative use of learning technology was noted. This is somewhat disconcerting considering that the role of technology in the development of a learner-centered environment has been discussed for years (Cullen, Harris, \& Hill, 2012; Barr \& Tagg, 1995; Patel-Junankar, 2018). Advances in new technologies have been recognized for having contributed to the development of online reforms in HE (O'Connor, 2020). Recently, Patel-Junankar (2018) mentioned that "learner-centered pedagogy is gaining ground in the realm of online education, where the concept of a classroom without walls harnesses the power of technology" (p. 8).

A global event that happened in early 2020 - COVID-19 - has changed the way we live and could impact educational provision for years (Vlachopoulos, 2020). In response to this sudden pandemic, everyone in HE institutions have had to change their way of doing things overnight, and the request for social distancing measures resulted in an unprecedented push for online learning and the use of the new technologies (Ali, 2020; Azorín, 2020; Hodges, Moore, Lockee, Trust, \& Bond, 2020). While we have been cautioned against making comparisons between effective online learning and emergency remote learning (Hodges et al., 2020; Chaka, 2020), we can examine the content of the first wave of articles regarding the impact of the COVID-19 on education and, by extension, on the learner-centered approach. The first observation is that, despite a gradual integration of online courses in HE institutions over the past decade (Sistek-Chandler, 2019), very few universities were prepared for the radical change imposed by the pandemic (Sutton \& Jorge, 2020). Second, attempts to develop contingency plans highlighted that the nature of HE education, pre-COVID-19, was predominately ICT (Sangster, Stoner, \& Flood, 2020). Third, some researchers were quick to promote the advantages and benefits of online courses, as technology allows students to have access to the teaching material anytime and anywhere (Naciri, Baba, Achbani, \& Kharbach, 2020). Others warn us of the advent of 'seller's market in ed-tech' with "possible problems arising from hasty adoption of commercial digital learning solutions whose design might not always be driven by best pedagogical practices” (Teräs, Suoranta, Teräs, \& Curcher, 2020, p. 1). Fourth, a major issue with this abrupt change to online-only teaching was how to avoid cheating during the evaluation process, which was a real concern for universities' academic reputations (Golden \& Kohlbeck, 2020). One solution has been to change the way the questions are worded: "when faced with a paraphrased test bank question, students cannot easily find the answer on the Internet because the question does not exist in a verbatim form online" (Golden \& Kohlbeck, 2020, p. 1). Other solutions proposed the use of innovative technologies such as asking students to purchase a camera and to record themselves during the exam or to use biometric gadgets to measure the heart rate and stress level of the students (Bilen \& Matrosa, 2020; Lee, Kim, Park, \& Henning, 2020). At the risk of sounding sarcastic, one could say that the COVID-19 has changed the balance of power in the 'game' by granting an advantage to students. However, the professors, with the agreement of the administration, are looking for ways to regain control.

In these turbulence times, it seems essential to understand that to develop effective online courses, the challenges are not only technical, they are also pedagogical and instructional (Ali, 2020), and that technology should support learning rather than adopting a technology-centered approach: "[...] just because something can be done with technology does not mean it should be done" (Mayer, 2019, p. 153). 


\section{Conclusion}

This case study demonstrated that it is possible to plan and deliver a course based on the LCT approach and make the majority of the students feel like they have learned and grown in a stress-free learning environment. However, generalization should be avoided due to cultural differences that influence the decisions and behaviors deemed acceptable. This is particularly true for a country as large as Brazil marked by economic and social inequalities, and unequal access to technology (De Araújo, Souza, \& Melo, 2020; Prata-Linhares, Cardoso, Lopes-Jr, \& Zukowsky-Tavares, 2020).

That being said, some results may guide our reflections on the place that the LCT approach should and will take on the educational scale. First, encouraging professors to move toward an LCT approach is a step in the right direction, but for HE to fulfil its mandate of helping students learn and grow to enjoy an uncertain future, changes must be made at all university levels. Second, with globalization and the constant advancement of technology, our relationship with the teaching-learning process will evolve to include a stronger presence of online courses, which have flourished because of COVID-19. Third, learning theories should influence the development and the choice of the most appropriate advances in technology. Finally, the evaluation of the students in remote learning is a challenge as it is approached using the traditional perspective where students are potential cheaters to get a higher grade than what they deserve. In a learning environment where the students can decide in advance how much effort they are willing to invest and therefore the grade to receive, then the cheating problem disappears.

\section{References}

Ali, W. (2020). Online and remote learning in higher education institutes: A necessity in light of COVID-19 pandemic. Higher Education Studies, 10(3), 1625 .

Araya, J., Bennie, A., \& O'Connor, D. (2015). Understanding performance coach development: Perceptions about a postgraduate coach education program. International Sport Coaching Journal, 2(1), 3-14.

Armour, K. (2010). The learning coach... the learning approach: Professional development for sports coach professionals. In: J. Lyle, \& C. Cushion (Eds.). Sports coaching: professionalisation and practice. London: Churchill Livingstone, 153-164.

Asikainen, H., \& Gijbels, D. (2017). Do students develop towards more deep approaches to learning during studies? A systematic review on the development of students' deep and surface approaches to learning in higher education. Educational Psychology Review, 29(2), 205-234.

Azorín, C. (2020). Beyond COVID-19 supernova. Is another education coming? Journal of Professional Capital and Community, $381-390$.

Baptista, T. J. R., Leite, J. O., Falcão, J. L. C., \& Flausino, M. S. (2015). Perfil atual da formação profissional em educação física no Brasil. In A. M. Silva, \& V. M. Bedoya (Orgs.). Formação profissional em educação física na América Latina: Encontros, diversidades e desafios. Jundiaí-SP: Paco Editorial, 55-75.

Barr, R. B., \& Tagg, J. (1995). From teaching to learning: A new paradigm for undergraduate education. Change Magazine. 27(6), 12-26.

Bilen, E., \& Matrosa, A. (2020). Online Cheating Amid COVID-19.

Blumberg, P. (2009). Developing learner-centered teaching: A practical guide for faculty. Jossey-Bass.

Callary, B., Culver, D., Werthner, P., \& Bales, J. (2014). An overview of seven national high performance coach education programs. International Sport Coaching Journal, 1(3), 152-164.

Chaka, C. (2020). Higher education institutions and the use of online instruction and online tools and resources during the COVID-19 outbreak-An online review of selected US and SA's universities.

Cullen, R., Harris, M., \& Hill, R. (2012). The learner-centered curriculum: Design and implementation. Jossey-Bass.

Cushion, C., \& Nelson, L. (2013). Coach education and learning: developing the field. In P Potrac, W. Gilbert, \& J. Denison (Eds.). Routledge handbook of sports coaching. Routledge, 359- 374.

De Araújo, L. T., Souza, A.D. S., \& Melo, A.C. P. C. (2020) Brazilian higher education: challenges and possible pedagogical strategies during covid-19 pandemic. International Journal of Informational Research. Review, 7(5), 6918-6920.

De Martin-Silva, L., Fonseca, J., Jones, R. L., Morgan, K., \& Mesquita, I. (2015). Understanding undergraduate sports coaching students' development and learning: the necessity of uncertainty. Teaching in Higher Education, 20(7), 669-683.

Dolmans, D. H., Loyens, S. M., Marcq, H., \& Gijbels, D. (2016). Deep and surface learning in problem-based learning: a review of the literature. Advances in health sciences education, 21(5), 1087-1112. 
Duffy, P., Hartley, H., Bales, J., Crespo, M., Dick, F., Vardhan, D., \& Curado, J. (2011). Sport coaching as a 'profession': Challenges and future directions. International Journal of Coaching Science, 5(2), 93-123.

Faranda, W. T., Clarke, T. B., \& Clarke III, I. (2020). Marketing Student Perceptions of Academic Program Quality and Relationships to Surface, Deep, and Strategic Learning Approaches. Journal of Marketing Education, 43(1), 9-24.

Galatti, L., Bettega, O. B., Brasil, V. Z., de Souza Sobrinho, A. E. P., Bertram, R., Tozetto, A. V. B., Rodrigues, H. A., Collet, C., Nascimento, J. V., \& Milistetd, M. (2016). Coaching in Brazil sport coaching as a profession in Brazil: an analysis of the coaching literature in Brazil from 2000-2015. International Sport Coaching Journal, 3(3), 316-331.

Gerritsen-van Leeuwenkamp, K. J., Joosten-ten Brinke, D., \& Kester, L. (2019). Students' perceptions of assessment quality related to their learning approaches and learning outcomes. Studies in Educational Evaluation, 63, 72-82.

Gilbert, W. D., \& Trudel, P. (2004). Analysis of coaching science research published from 1970-2001. Research quarterly for exercise and sport, 75(4), 388399.

Golden, J., \& Kohlbeck, M. (2020). Addressing cheating when using test bank questions in online Classes. Journal of Accounting Education, $52,100671$.

Griffo, J. M., Jensen, M., Anthony, C. C., Baghurst, T., \& Kulinna, P. H. (2019). A decade of research literature in sport coaching (2005-2015). International Journal of Sports Science \& Coaching, 14(2), 205-215.

Harris, M., Cullen, R. (2010). Leading the learner-centered campus. Jossey-Bass.

Hodges, C., Moore, S., Lockee, B., Trust, T., \& Bond, A. (2020). The difference between emergency remote teaching and online learning. Educause review, 27, 1-12.

Jones, R. L., \& Turner, P. (2006). Teaching coaches to coach holistically: Can problem-based learning (PBL) help? Physical Education and Sport Pedagogy, 11(2), 181-202.

Lara-Bercial, S., Abraham, A., Colmaire, P., Dieffenbach, K., Mokglate, O., Rynne, S., \& Nordmann, L. (2016). The international sport coaching bachelor degree standards of the international council for coaching excellence. International Sport Coaching Journal, 3(3), 344-348.

Lee, J., Kim, R. J., Park, S. Y., \& Henning, M. A. (2020). Using technologies to prevent cheating in remote assessments during the COVID-19 pandemic. Journal of dental education, 1-3.

Mallett, C., Rynne, S., \& Dickens, S. (2013). Developing high performance coaching craft through work and study. In P. Potrac, W. Gilbert, \& J. Denison (Eds.). Routledge handbook of sports coaching. London: Routledge, 481-493.

Mayer, R. E. (2019). Thirty years of research on online learning. Applied Cognitive Psychology, 33(2), 152-159.

McCarthy, L., \& Stoszkowski, J. (2018). A heutagogical approach to coach education: What worked for one particular learner, how and why. Journal of Qualitative Research in Sports Studies, 12(1), 317-336.

Menezes, R. P., Modolo, F., Dos Santos, W. R., \& Musa, V. D. S. (2017). Influence of normative institutions of handball for coaches learning: standpoint of Sao Paulo state coaches, E-Balonmano.com - Revista de Ciencias del Deporte, 13(3), 183-190.

Milistetd, M., Ciampolini, V., Mendes, M. S., Cortela, C. C., \& do Nascimento, J. V. (2018). Student-coaches perceptions about their learning activities in the university context. Revista Brasileira de Ciências do Esporte, 40(3), 281-287.

Milistetd, M., Ciampolini, V., Salles, W. D. N., Ramos, V., Galatti, L. R., \& Nascimento, J. V. D. (2016). Coaches' development in Brazil: Structure of sports organizational programmes. Sports Coaching Review, 5(2), 138-152.

Milistetd, M., Salles, W. D. N., Backes, A. F., Mesquita, I., \& Nascimento, J. V. D. (2019). Learner-centered teaching in a university-based coach education: First attempts through action research inquiry. International Journal of Sports Science \& Coaching, 14(3), 294-309.

Milistetd, M., Salles, W., Trudel, P., \& Paquette, K. (2019). Making direct teaching more learner-centered in University-based coach education courses. In B. Callary, \& B. Gearity (Eds.). Coach education and development in sport: instructional strategies. London: Routledge, 7-19.

Milistetd, M., Trudel, P., Mesquita, I., \& do Nascimento, J. V. (2014). Coaching and coach education in Brazil. International Sport Coaching Journal, 1(3), $165-172$.

Milistetd, M., Trudel, P., Rynne, S., Mesquita, I. M. R., \& do Nascimento, J. V. (2018). The learner-centred status of a Brazilian university coach education program. International Sport Coaching Journal, 5(2), 105-115.

Moon, B., Hoffman, R. R., Novak, J. D., \& Canas, A. (Eds.). (2011). Applied concept mapping: Capturing, analyzing, and organizing knowledge. CRC Press.

Morgan, K., Jones, R. L., Gilbourne, D., \& Llewellyn, D. (2013). Changing the face of coach education: Using ethno-drama to depict lived realities. Physical Education and Sport Pedagogy, 18(5), 520-533.

Naciri, A., Baba, M. A., Achbani, A., \& Kharbach, A. (2020). Mobile learning in Higher education: Unavoidable alternative during COVID19. Aquademia, 4(1), ep20016.

Novak, J. D. (2010). Learning, creating, and using knowledge: Concept maps as facilitative tools in schools and corporations. Routledge.

O'Connor, K. (2020). Constructivism, curriculum and the knowledge question: tensions and challenges for higher education. Studies in Higher Education, 111 . 
Paquette, K., \& Trudel, P. (2016). Learner-centered teaching: A consideration for revitalizing coach education. The psychology of effective coaching and management, Nova Science, 53-70.

Paquette, K., \& Trudel, P. (2018). Learner-centered coach education: Practical recommendations for coach development administrators. International Sport Coaching Journal, 5(2), 169-175.

Patel-Junankar, D. (2018). Learner-Centered Pedagogy: Teaching and Learning in the 21st Century. In G. Kayingo, \& V. McCoy Hass (Eds.). The Health Professions Educator: A Practical Guide for New and Established Faculty. Springer Publishing Company, 3-12.

Pitino, R. (2000). Lead to Success: ten traits of great leadership in business and life. Broadway Books.

Prata-Linhares, M. M., Cardoso, T. D. S. G., Lopes-Jr, D. S., \& Zukowsky-Tavares, C. (2020). Social distancing effects on the teaching systems and teacher education programmes in Brazil: reinventing without distorting teaching. Journal of Education for Teaching, 46(4), 554-564.

Rodrigue, F., He, C., \& Trudel, P. (2016). Concept mapping: Its use for high-performance sport coach development. In P. A. Davis (Ed.). The psychology of effective coaching and management. ova Science Publishers.

Sangster, A., Stoner, G., \& Flood, B. (2020). Insights into accounting education in a COVID-19 world. Accounting Education, $29(5), 431-562$.

Schmidt, H. G., Rotgans, J. I., \& Yew, E. H. J. (2019). Cognitive constructivist foundations of problem-based learning. In M. Moallem, W. Hung, \& N. Dabbagh (Eds.). The Wiley Handbook of Problem-Based Learning. John Wiley \& Sons, Inc, 25-50.

Schweisfurth, M. (2015). Learner-centered pedagogy: Towards a post-2015 agenda for teaching and learning. International Journal of Educational Development, 40, 259-266.

Sistek-Chandler, C. M. (2019). Exploring Online Learning Through Synchronous and Asynchronous Instructional Methods. IGI Global.

Sparkes A. C., Smith, B. (2014). Qualitative research methods in sports, exercise and health: From process to product. Routledge.

Stodter, A, \& Cushion, C. (2016). Effective coach learning and processes of coaches' knowledge development: What works? In P. A. Davis (Ed.). The psychology of effective coaching and management. Nova Science, 35-51.

Sutton, M. J., \& Jorge, C. F. B. (2020). Potential for radical change in Higher Education learning spaces after the pandemic. Journal of Applied Learning and Teaching, 3(1), 124-128.

Teräs, M., Suoranta, J., Teräs, H., \& Curcher, M. (2020). Post-Covid-19 education and education technology 'solutionism': A seller's market. Postdigital Science and Education, 2(3), 863-878.

Trudel, P., Culver, D., \& Werthner, P. (2013). Looking at coach development from the coach-learner's perspective: Consideration for coach development administrators. In P. Potrac, W. Gilbert, \& J Denison (Eds.). Routledge handbook of sports coaching. Routledge, $375-387$.

Trudel, P., Gilbert, W., \& Rodrigue, F. (2016). The journey from competent to innovator: Using Appreciative Inquiry to enhance high performance coaching. AI Practitioner, 18(2); 40-46.

Trudel, P., Gilbert, W., \& Werthener, P. (2010). Coach education effectiveness. In J. Lyle, \& C. Cushion (Orgs.). Sports coaching: professionalisation and practice. London: Elsevier, 135-152.

Trudel, P., Milistetd, M., \& Culver, D. M. (2020). What the empirical studies on sport coach education programs in higher education have to reveal: A review. International Sport Coaching Journal, 7(1), 61-73.

Vella, S. A., Crowe, T. P., \& Oades, L. G. (2013). Increasing the effectiveness of formal coach education: Evidence of a parallel process. International Journal of Sports Science \& Coaching, 8(2), 417-430.

Vlachopoulos, D. (2020). COVID-19: threat or opportunity for online education? Higher Learning Research Communications, 10(1), 2.

Weimer, M. (2002). Learner-centered teaching: Five key changes to practice. Jossey-Bass.

Weimer, M. (2013). Learner-centered teaching: Five key changes to practice. (2nd ed.), Jossey-Bass.

Werthner, P., \& Trudel, P. (2009). Investigating the idiosyncratic learning paths of elite Canadian coaches. International Journal of Sports Science \& Coaching, 4(3), 433-449.

Wiersma, L. D., \& Sherman, C. P. (2005). Volunteer youth sport coaches' perspectives of coaching education/certification and parental codes of conduct. Research quarterly for exercise and sport, 76(3), 324-338.

Zakrajsek, R., Thompson, M., \& Dieffenbach, K. (2015). An exploration of the academic coaching education internship. Sports Coaching Review, 4(1), 24-40. 